\title{
Assessment of gas production and electrochemical factors for fracturing flow-back fluid treatment in Guangyuan oilfield
}

\author{
Yang Liu ${ }^{1,2}$, Wu Chen ${ }^{1,2^{\dagger}}$, Shanhui Zhang ${ }^{1,2}$, Dongpo Shi ${ }^{1,2}$, Mijia Zhu ${ }^{1,2^{\dagger}}$ \\ ${ }^{1}$ School of Chemistry and Environmental Engineering, Yangtze University, Jingzhou 434023, China \\ ${ }^{2}$ State Key Laboratory of Petroleum Pollution Control, HSE Key Laboratory, CNPC Research Institute of Safety and Environmental Technology, Beijing 102206, China
}

\begin{abstract}
Electrochemical method was used for the fracturing flow-back fluid treatment in Guangyuan oilfield. After performing electrolysis, we found that the amount of $\mathrm{H}_{2}$ gas produced by electrode was closely related to the combination mode of electrodes and electrode materials. Using an aluminium electrode resulted in a large $\mathrm{H}_{2}$ production of each electrode combination, whereas inert anode and cathode materials resulted in low $\mathrm{H}_{2}$ production. Then, the relationship between the gas production of $\mathrm{H}_{2}$ and the treatment efficiency of fracturing flow-back fluid in Guangyuan oilfield was studied. Results showed that the turbidity removal and decolourisation rates of fracturing flow-back fluid were high when $\mathrm{H}_{2}$ production was high. If the $\mathrm{H}_{2}$ production of inert electrode was large, the energy consumption of this inert electrode was also high. However, energy consumption when an aluminium anode material was used was lower than that when the inert electrode was used, whereas the corresponding electrode combination production of $\mathrm{H}_{2}$ was larger than that of the inert electrode combination. When the inert electrode was used as anode, the gas production type was mainly $\mathrm{O}_{2}$, and $\mathrm{Cl}_{2}$ was also produced and dissolved in water to form $\mathrm{ClO}^{-}$. $\mathrm{H}_{2}$ production at the cathode was reduced because $\mathrm{ClO}^{-}$obtained electrons.
\end{abstract}

Keywords: Aluminium electrode, Electrolysis, Hydrogen evolution, $\mathrm{H}_{2}$ production, Inert electrode

\section{Introduction}

Fracturing flow-back fluid is one of the main pollutants produced in oilfield exploitation [1-2]. The composition of flow-back fluid is extremely complex. Further treatment of all types of organic pollutants in waste fluid is necessary prior to its reuse or discharge. Electrochemical method is an effective way for processing fracturing flow-back fluid in oilfield [3] and involves electrocoagulation [4-6], electrolytic flotation [7-9], and electrochemical oxidation methods [10-13]. These electrochemical methods produce a considerable amount of gases, such as $\mathrm{H}_{2}, \mathrm{O}_{2}$ or $\mathrm{Cl}_{2}$, in the electrode during the fracturing fluid treatment [14-15]. $\mathrm{O}_{2}, \mathrm{Cl}_{2}$ and other strong oxidising gases are often comprehensively involved in the reaction of degraded or oxidised organic compounds in wastewater, which cause a significant decrease in their electrolytic production. Therefore, these gases do not evidently harm the environment. However, $\mathrm{H}_{2}$ produced by the cathode is difficult to consume in the electrolysis process and thus a major safety hazard during the electrochemical treatment of fracturing flow-back fluid. Research on electrochemical treatment of fracturing flow-back fluid in oilfield mainly focuses on treatment effect, and no systematic report on the study of $\mathrm{H}_{2}$ electrode analysis is currently available. Therefore, the Guangyuan oilfield fracturing flow-back fluid was considered as the processing object in this study. The amount of $\mathrm{H}_{2}$ produced and the effect of different electrodes and electrode combinations on the treatment of fracturing flow-back fluid were analysed. Simultaneously, the influence of current, electrolysis time and electrode plate spacing on $\mathrm{H}_{2}$ production was investigated. This study aims to serve as a reference for the analysis of the $\mathrm{H}_{2}$ evolution regular pattern in treating oilfield fracturing flow-back fluid using the electrochemical method.

\section{Materials and Methods}

\subsection{Materials}

The experimental fracturing flow-back fluid was obtained from the storage pool of fracturing flow-back liquid in Guangyuan oil

Received February 14, 2018 Accepted November 14, 2018

${ }^{\dagger}$ Corresponding author

Email: ccww91@126.com, zhumijia128@163.com

Tel: +86-716-8060472 Fax: +86-716-8060472

ORCID: 0000-0003-0061-8305 (M. Zhu)

Copyright (c) 2019 Korean Society of Environmental Engineers 

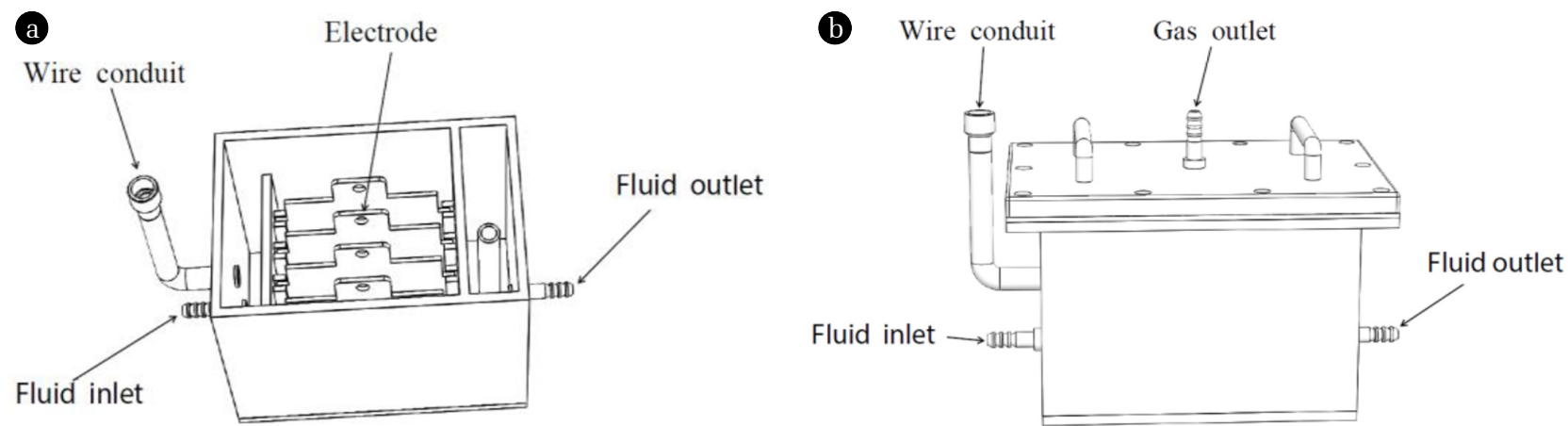

Fig. 1. Electrolysis treatment unit ((a): internal diagram; (b): external diagram).

and gas field of PetroChina. The electrode materials in the study included aluminium electrode (Al), titanium electrode (Ti), zirconium electrode $(\mathrm{Zr})$, special ruthenium and iridium composite coating electrode $\left(\mathrm{Ti} / \mathrm{RuO}_{2}-\mathrm{IrO}_{2}\right.$, adapt to neutral and acid environment), ruthenium and iridium composite coating electrode ( $\mathrm{Ti} / \mathrm{RuO}_{2}-\mathrm{IrO}_{2}$, adapt to basic environment), special ruthenium and iridium palladium composite coating electrode $\left(\mathrm{Ti} / \mathrm{RuO}_{2}-\right.$ $\mathrm{IrO}_{2}-\mathrm{PdO}$, adapt to neutral and acid environment) and ruthenium and iridium palladium composite coating electrode $\left(\mathrm{Ti} / \mathrm{RuO}_{2}-\right.$ $\mathrm{IrO}_{2}$-PdO, adapt to basic environment). The standard dimension was $100 \mathrm{~mm} \times 90 \mathrm{~mm} \times 3 \mathrm{~mm}$. The electrode materials were produced by Baoji Longsheng non-ferrous Pioneer Metals Company (China). Electrolytic tank was used for the collection of gas from waste liquid through electrochemical treatment. The main components of the electrolytic tank included electrolysis, buffer and overflow rooms (showed in Fig. 1). The dimensions of the electrolysis, buffer, and overflow rooms were $120 \mathrm{~mm} \times$ $144 \mathrm{~mm} \times 105 \mathrm{~mm}$ (Total volume: 1,814.4 mL), $20 \mathrm{~mm} \times 144$ $\mathrm{mm} \times 135 \mathrm{~mm}$ (Total volume: $388.8 \mathrm{~mL}$ ) and $30 \mathrm{~mm} \times 144$ $\mathrm{mm} \times 105 \mathrm{~mm}$ (Total volume: $583.2 \mathrm{~mL}$ ), respectively. The tank was produced by the Feihong Plexiglass Products Company in Wuhan (China). DC regulated power supply type was XR (Shanghai Yize Electric Co., Ltd., China) (input voltage: $220 \mathrm{~V}+10 \%$, 50 $\mathrm{Hz}+1 \mathrm{~Hz}$; output voltage: 0-60 V; output current: 0-30 A).

\subsection{Electrochemical Experiments}

A total of $800 \mathrm{~mL}$ fracturing flow-back fluid from Guangyuan oil field was added to the electrolytic tank before the electrochemical process. Half of the electrodes were immersed in the solution, and the effective surface area of the electrode was 4,500 $\mathrm{mm}^{2}$. The electrode material and electrode combination mode were changed, and the relationship among the $\mathrm{H}_{2}$ production rate, energy consumption, decolourisation and turbidity removal rates of waste fluid in combination with different electrode materials was analysed. The parameters of electrochemical process, a direct current (DC) range of 0-2.5 A, an electrode plate spacing range of 2-10 $\mathrm{cm}$ and an electrolysis time range of 0-70 min were also examined. The batch experiments were conducted at room temperature $\left(20^{\circ} \mathrm{C}\right)$.

\subsection{Analysis Methods}

The ion chromatograph ICS-2100 was from Thermo Fisher
Scientific Co. Ltd. The electronic microbalance type was Sartorius BP211D (Switzerland) with a precision of $0.01 \mathrm{mg}$. The multifunction complex gas analyser was GT-2000 (Shenzhen city Kolno Electronic Technology Co., Ltd., China) with 1\% - 3\% precision. The gas mass flowmetre and cumulant indicator type was MFM610-RS232 (Suzhou Aituo Electronic Equipment Co., Ltd., China) with a range of $0-300 \mathrm{~mL} / \mathrm{min}$.

The colourity of the solutions described by Zeng et al. [16] was performed on a 751-GW UV/vis spectrophotometer (Inesa analytical instrument Co., Ltd., Shanghai, China). The maximum absorption wavelength at $339 \mathrm{~nm}$ was obtained by determining the colourity values. Standard solution samples were prepared from a commercial concentrated platinum cobalt colour solution. The samples were used for instrument calibration and for the development of a standard curve of colour and absorbance. The $R^{2}$ value associated with this curve was 0.9999 . Colourity removal performance was calculated with the following equation: $R \%=$ $\left[\left(A_{0}-A\right) / A_{0}\right] \times 100$. The turbidity metre was Orion AQ2010 (Thermo Electron Corporation).

The mechanism of gas production in electrolysis was analysed by means of oxygen evolution potential, chloride evolution potential and polarization curve. The oxygen evolution potential of electrode in $0.5 \mathrm{~mol} / \mathrm{L}$ sulphate water solution, the chlorine evolution potential of electrode in saturated $\mathrm{NaCl}$ aqueous solution and the Tafel polarization curve of electrode in fracturing flow-back fluid sample were obtained on the CS350H electrochemical workstation (Wuhan Corrtest Instruments Co., Ltd., China).

\section{Results and Discussion}

\subsection{Effect of Electrode Materials on $\mathrm{H}_{2}$ Production}

When the Ti, $\mathrm{Al}$ and $\mathrm{Ti} / \mathrm{RuO}_{2}-\mathrm{IrO}_{2}-\mathrm{PdO}$ were used as anode, $\mathrm{Al}$, $\mathrm{Ti}, \mathrm{Zr}, \mathrm{Ti} / \mathrm{RuO}_{2}-\mathrm{IrO}_{2}$ and special $\mathrm{Ti} / \mathrm{RuO}_{2}-\mathrm{IrO}_{2}, \mathrm{Ti} / \mathrm{RuO}_{2}-\mathrm{IrO}_{2}-\mathrm{PdO}$ and special $\mathrm{Ti} / \mathrm{RuO}_{2}-\mathrm{IrO}_{2}-\mathrm{PdO}$ were used as cathode, respectively. Results of $\mathrm{H}_{2}$ gas production in the electrochemical process are described in Table 1.

Table 1 shows that when the cathode material was soluble aluminium electrode, the $\mathrm{H}_{2}$ production $\left(V_{\mathrm{a}}\right)$ of the electrode combination was the largest, reaching $36.00,45.85$ and $45.98 \mathrm{~mL}$. When the cathode material was a special $\mathrm{Ti} / \mathrm{RuO}_{2}-\mathrm{IrO}_{2}-\mathrm{PdO}$ inert 
Table 1. Effect of Electrode Materials on $\mathrm{H}_{2}$ Production

\begin{tabular}{|c|c|c|c|}
\hline Serial number & Cathode & Anode & $\mathrm{H}_{2}$ production/mL \\
\hline 1 & \multirow{3}{*}{$\mathrm{Al}$} & $\mathrm{Ti} / \mathrm{RuO}_{2}-\mathrm{IrO}_{2}-\mathrm{PdO}$ & 36.00 \\
\hline 2 & & $\mathrm{Ti}$ & 45.85 \\
\hline 3 & & $\mathrm{Al}$ & 45.98 \\
\hline 4 & \multirow{3}{*}{$\mathrm{Ti}$} & $\mathrm{Ti} / \mathrm{RuO}_{2}-\mathrm{IrO}_{2}-\mathrm{PdO}$ & 28.57 \\
\hline 5 & & $\mathrm{Ti}$ & 38.85 \\
\hline 6 & & $\mathrm{Al}$ & 45.87 \\
\hline 7 & \multirow{3}{*}{$\mathrm{Zr}$} & $\mathrm{Ti} / \mathrm{RuO}_{2}-\mathrm{IrO}_{2}-\mathrm{PdO}$ & 25.02 \\
\hline 8 & & $\mathrm{Ti}$ & 34.83 \\
\hline 9 & & $\mathrm{Al}$ & 41.64 \\
\hline 10 & \multirow{3}{*}{ Special $\mathrm{Ti} / \mathrm{RuO}_{2}-\mathrm{IrO}_{2}$} & $\mathrm{Ti} / \mathrm{RuO}_{2}-\mathrm{IrO}_{2}-\mathrm{PdO}$ & 24.87 \\
\hline 11 & & $\mathrm{Ti}$ & 37.31 \\
\hline 12 & & $\mathrm{Al}$ & 42.90 \\
\hline 13 & \multirow{3}{*}{$\mathrm{Ti} / \mathrm{RuO}_{2}-\mathrm{IrO}_{2}$} & $\mathrm{Ti} / \mathrm{RuO}_{2}-\mathrm{IrO}_{2}-\mathrm{PdO}$ & 25.89 \\
\hline 14 & & $\mathrm{Ti}$ & 38.63 \\
\hline 15 & & $\mathrm{Al}$ & 43.83 \\
\hline 16 & \multirow{3}{*}{ Special $\mathrm{Ti} / \mathrm{RuO}_{2}-\mathrm{IrO}_{2}-\mathrm{PdO}$} & $\mathrm{Ti} / \mathrm{RuO}_{2}-\mathrm{IrO}_{2}-\mathrm{PdO}$ & 19.94 \\
\hline 17 & & $\mathrm{Ti}$ & 34.29 \\
\hline 18 & & $\mathrm{Al}$ & 38.87 \\
\hline 19 & \multirow{3}{*}{$\mathrm{Ti} / \mathrm{RuO}_{2}-\mathrm{IrO}_{2}-\mathrm{PdO}$} & $\mathrm{Ti} / \mathrm{RuO}_{2}-\mathrm{IrO}_{2}-0 \mathrm{PdO}$ & 27.68 \\
\hline 20 & & $\mathrm{Ti}$ & 37.93 \\
\hline 21 & & $\mathrm{Al}$ & 41.76 \\
\hline
\end{tabular}

electrode, the $\mathrm{H}_{2}$ production $\left(V_{\mathrm{s}}\right)$ of the electrode combination was the lowest at 19.94, 34.29 and $38.87 \mathrm{~mL}$. These results were equivalent to $55.39 \%, 74.78 \%$ and $84.54 \%$ of the $\mathrm{H}_{2}$ production $\left(V_{\mathrm{s}} / V_{\mathrm{a}}\right)$ when the cathode material was aluminium electrode. Different electrode materials considerably influenced $\mathrm{H}_{2}$ production. $\mathrm{H}_{2}$ production was low when the anode and cathode materials were both inert electrodes (however, $\mathrm{H}_{2}$ production of different inert electrode combinations were different) due to the high potential inert electrode of $\mathrm{H}_{2}$ and $\mathrm{O}_{2}$. A high $\mathrm{O}_{2}$ potential can lead to $\mathrm{Cl}_{2}$ production of the anode. Apart from $\mathrm{H}_{2}$ production, electron consumption of $\mathrm{ClO}^{-}$led to the reduction of $\mathrm{H}_{2}$ production when the current and electrolysis time were the same and the inert electrode was used as cathode [17-19].

\subsection{Relationship between $\mathrm{H}_{2}$ Production and Electrochemical Treatment Efficiency}

The effect of different types of electrode combination on the colourity and turbidity removal rate in fracturing flow-back fluid treatment is shown in Table 2, where the range of turbidity removal and decolourisation rates were $54.26 \%-62.77 \%$ and $37.92 \%$ $39.75 \%$, respectively, when $\mathrm{Ti} / \mathrm{RuO}_{2}-\mathrm{IrO}_{2}-\mathrm{PdO}$ was used as an anode. When $\mathrm{Al}$ was used as an anode, the range of the turbidity removal and decolourisation rates reached $98.37 \%-98.74 \%$ and $85.67 \%$ - 87.82\%, respectively. Table 1 shows that when the cathode material of the electrode was the same and when the $\mathrm{Ti} / \mathrm{RuO}_{2}-\mathrm{IrO}_{2}-\mathrm{PdO}, \mathrm{Ti}$ and $\mathrm{Al}$ were used as anode, $\mathrm{H}_{2}$ production increased, showing that $\mathrm{H}_{2}$ production is related to the turbidity removal and decolourisation rates of the fracturing flow-back fluid in the Guangyuan oilfield.

$\mathrm{H}_{2}$ production resulted in high turbidity removal and decolourisation rates in the treatment of the fracturing flow-back fluid. $\mathrm{Al}$ anode yielded the highest $\mathrm{H}_{2}(45.98 \mathrm{~mL})$ and resulted in the highest turbidity removal and decolourisation rate $(98.74 \%$ and $87.82 \%$, respectively). By contrast, the $\mathrm{Ti} / \mathrm{RuO}_{2}-\mathrm{IrO}_{2}-\mathrm{PdO}$ anode and special $\mathrm{Ti} / \mathrm{RuO}_{2}-\mathrm{IrO}_{2}-\mathrm{PdO}$ cathode produced $19.94 \mathrm{~mL}$ of $\mathrm{H}_{2}$, with turbidity removal and decolourisation rate of $54.26 \%$ and $38.03 \%$, respectively. When the current and electrolysis time were the same, the electrode combination, which produces considerable amount of $\mathrm{H}_{2}$, usually exerts a satisfactory treatment effect. However, the safety of the electrolysis process must be considered because of the large production capacity of $\mathrm{H}_{2}$.

\subsection{Relationship between $\mathrm{H}_{2}$ Production and Energy Consumption}

The effect of different types of electrode combinations on the colourity and turbidity removal rate from fracturing flow-back fluid treatment is shown in Table 2. The energy consumption assessments of fracturing flow-back fluid treatment under different types of electrode combination are shown in Table 3.

Table 3 shows that when $\mathrm{Al}, \mathrm{Ti} / \mathrm{RuO}_{2}-\mathrm{IrO}_{2}-\mathrm{PdO}$, Ti was used as anode, the energy consumption range of the electrode combinations was 26-28, 26-30 and 34-36 W-h, respectively. From Table 1-3, electricity consumption increased with the increase of $\mathrm{H}_{2}$ production, turbidity removal and decolourisation rate. However, the comparative analysis results in Table 1 and 2 show that when $\mathrm{Al}$ was used as the anode, $\mathrm{H}_{2}$ production, turbidity removal and decolourisation rate of the electrode combinations was high, 
Table 2. Effect of Electrode Materials on Turbility Removal Rate and Decolourisation Rate

\begin{tabular}{|c|c|c|c|c|}
\hline Serial number & Cathode & Anode & Turbidity removal rate/\% & Decolourisation rate/\% \\
\hline 1 & \multirow{3}{*}{$\mathrm{Al}$} & $\mathrm{Ti} / \mathrm{RuO}_{2}-\mathrm{IrO}_{2}-\mathrm{PdO}$ & 57.45 & 39.75 \\
\hline 2 & & $\mathrm{Ti}$ & 97.12 & 87.22 \\
\hline 3 & & $\mathrm{Al}$ & 98.74 & 87.82 \\
\hline 4 & \multirow{3}{*}{$\mathrm{Ti}$} & $\mathrm{Ti} / \mathrm{RuO}_{2}-\mathrm{IrO}_{2}-\mathrm{PdO}$ & 60.64 & 38.74 \\
\hline 5 & & $\mathrm{Ti}$ & 95.32 & 86.12 \\
\hline 6 & & $\mathrm{Al}$ & 98.38 & 86.45 \\
\hline 7 & \multirow{3}{*}{$\mathrm{Zr}$} & $\mathrm{Ti} / \mathrm{RuO}_{2}-\mathrm{IrO}_{2}-\mathrm{PdO}$ & 62.77 & 38.22 \\
\hline 8 & & $\mathrm{Ti}$ & 95.50 & 85.92 \\
\hline 9 & & $\mathrm{Al}$ & 98.56 & 87.01 \\
\hline 10 & \multirow{3}{*}{ Special $\mathrm{Ti} / \mathrm{RuO}_{2}-\mathrm{IrO}_{2}$} & $\mathrm{Ti} / \mathrm{RuO}_{2}-\mathrm{IrO}_{2}-\mathrm{PdO}$ & 57.45 & 38.13 \\
\hline 11 & & $\mathrm{Ti}$ & 94.95 & 84.27 \\
\hline 12 & & $\mathrm{Al}$ & 98.55 & 85.75 \\
\hline 13 & \multirow{3}{*}{$\mathrm{Ti} / \mathrm{RuO}_{2}-\mathrm{IrO}_{2}$} & $\mathrm{Ti} / \mathrm{RuO}_{2}-\mathrm{IrO}_{2}-\mathrm{PdO}$ & 58.51 & 37.92 \\
\hline 14 & & $\mathrm{Ti}$ & 95.32 & 86.05 \\
\hline 15 & & $\mathrm{Al}$ & 98.37 & 86.27 \\
\hline 16 & \multirow{3}{*}{ Special $\mathrm{Ti} / \mathrm{RuO}_{2}-\mathrm{IrO}_{2}-\mathrm{PdO}$} & $\mathrm{Ti} / \mathrm{RuO}_{2}-\mathrm{IrO}_{2}-\mathrm{PdO}$ & 54.26 & 38.03 \\
\hline 17 & & $\mathrm{Ti}$ & 95.14 & 87.05 \\
\hline 18 & & $\mathrm{Al}$ & 98.72 & 86.92 \\
\hline 19 & \multirow{3}{*}{$\mathrm{Ti} / \mathrm{RuO}_{2}-\mathrm{IrO}_{2}-\mathrm{PdO}$} & $\mathrm{Ti} / \mathrm{RuO}_{2}-\mathrm{IrO}_{2}-\mathrm{PdO}$ & 58.51 & 38.72 \\
\hline 20 & & $\mathrm{Ti}$ & 95.32 & 85.75 \\
\hline 21 & & $\mathrm{Al}$ & 98.38 & 85.67 \\
\hline
\end{tabular}

Table 3. Effect of Electrode Materials on Energy Consumption

\begin{tabular}{|c|c|c|c|}
\hline Serial number & Cathode & Anode & Energy consumption/W•h \\
\hline 1 & \multirow{3}{*}{$\mathrm{Al}$} & $\mathrm{Ti} / \mathrm{RuO}_{2}-\mathrm{IrO}_{2}-\mathrm{PdO}$ & 30.00 \\
\hline 2 & & $\mathrm{Ti}$ & 34.00 \\
\hline 3 & & $\mathrm{Al}$ & 26.00 \\
\hline 4 & \multirow{3}{*}{$\mathrm{Ti}$} & $\mathrm{Ti} / \mathrm{RuO}_{2}-\mathrm{IrO}_{2}-\mathrm{PdO}$ & 26.00 \\
\hline 5 & & $\mathrm{Ti}$ & 34.00 \\
\hline 6 & & $\mathrm{Al}$ & 27.00 \\
\hline 7 & \multirow{3}{*}{$\mathrm{Zr}$} & $\mathrm{Ti} / \mathrm{RuO}_{2}-\mathrm{IrO}_{2}-\mathrm{PdO}$ & 27.00 \\
\hline 8 & & $\mathrm{Ti}$ & 36.00 \\
\hline 9 & & $\mathrm{Al}$ & 27.00 \\
\hline 10 & \multirow{3}{*}{ Special $\mathrm{Ti} / \mathrm{RuO}_{2}-\mathrm{IrO}_{2}$} & $\mathrm{Ti} / \mathrm{RuO}_{2}-\mathrm{IrO}_{2}-\mathrm{PdO}$ & 28.00 \\
\hline 11 & & $\mathrm{Ti}$ & 36.00 \\
\hline 12 & & $\mathrm{Al}$ & 27.00 \\
\hline 13 & \multirow{3}{*}{$\mathrm{Ti} / \mathrm{RuO}_{2}-\mathrm{IrO}_{2}$} & $\mathrm{Ti} / \mathrm{RuO}_{2}-\mathrm{IrO}_{2}-\mathrm{PdO}$ & 29.00 \\
\hline 14 & & $\mathrm{Ti}$ & 36.00 \\
\hline 15 & & $\mathrm{Al}$ & 28.00 \\
\hline 16 & \multirow{3}{*}{ Special $\mathrm{Ti} / \mathrm{RuO}_{2}-\mathrm{IrO}_{2}-\mathrm{PdO}$} & $\mathrm{Ti} / \mathrm{RuO}_{2}-\mathrm{IrO}_{2}-\mathrm{PdO}$ & 29.00 \\
\hline 17 & & $\mathrm{Ti}$ & 35.00 \\
\hline 18 & & $\mathrm{Al}$ & 26.00 \\
\hline 19 & \multirow{3}{*}{$\mathrm{Ti} / \mathrm{RuO}_{2}-\mathrm{IrO}_{2}-\mathrm{PdO}$} & $\mathrm{Ti} / \mathrm{RuO}_{2}-\mathrm{IrO}_{2}-\mathrm{PdO}$ & 29.00 \\
\hline 20 & & $\mathrm{Ti}$ & 35.00 \\
\hline 21 & & $\mathrm{Al}$ & 27.00 \\
\hline
\end{tabular}


although their energy consumption was low. These findings may be attributed to the soluble $\mathrm{Al}$ electrode. Al electrode was not only rapidly dissolved but also generated the flocculation effect of aluminium hydroxide flocs. The various pollutants in the form of floc sedimentation, which resulted in the consumption of the same electric energy, significantly increased turbidity removal and decolourisation rate $[20,21]$. This finding may be due to the relatively low $\mathrm{H}_{2}$ potential of the $\mathrm{Al}$ electrode, which resulted in an increase in the current efficiency during the electrochemical treatment, thereby reducing the energy consumption and causing $\mathrm{H}_{2}$ evolution [17-19].

\subsection{Effect of Different Electrolysis Condition on $\mathrm{H}_{2}$ Production of $\mathrm{Al}+\mathrm{l}-\mathrm{Al}(-)$ Electrode Combination}

Table 1 shows that when $\mathrm{Al}(+)-\mathrm{Al}(-)$ electrode combination was used in the fracturing flow-back fluid treatment, $\mathrm{H}_{2}$ production was the largest under the same electrolysis conditions. Therefore, the $\mathrm{Al}(+)-\mathrm{Al}(-)$ electrode combination was selected as a sample, the effect of electrolysis time, electrolysis current and electrode plate spacing on the $\mathrm{H}_{2}$ production were shown in Fig. 2-4.

Fig. 2 shows that $\mathrm{H}_{2}$ production from the electrode combination linearly increased with prolonged electrolysis under the same electrolysis conditions when the $\mathrm{Al}(+)-\mathrm{Al}(-)$ electrode combination was used. This finding indicates that the electrochemical reactor uses the $\mathrm{Al}(+)-\mathrm{Al}(-)$ electrode combination for a long time for waste fluid treatment. $\mathrm{H}_{2}$ production linearly increased, and the risk due to $\mathrm{H}_{2}$ also increased.

Fig. 3 shows that with the combination of $\mathrm{Al}(+)-\mathrm{Al}(-)$ electrode, $\mathrm{H}_{2}$ production from the electrode combination increases with increasing electrolysis current under the same electrolysis conditions. The increase rate also rises with increasing of electrolysis current. Increasing the electrolysis current was clearly beneficial to the production of $\mathrm{H}_{2}$ from the $\mathrm{Al}(+)-\mathrm{Al}(-)$ electrode combination. The main reactions occurring at the anode and cathode are as follows:

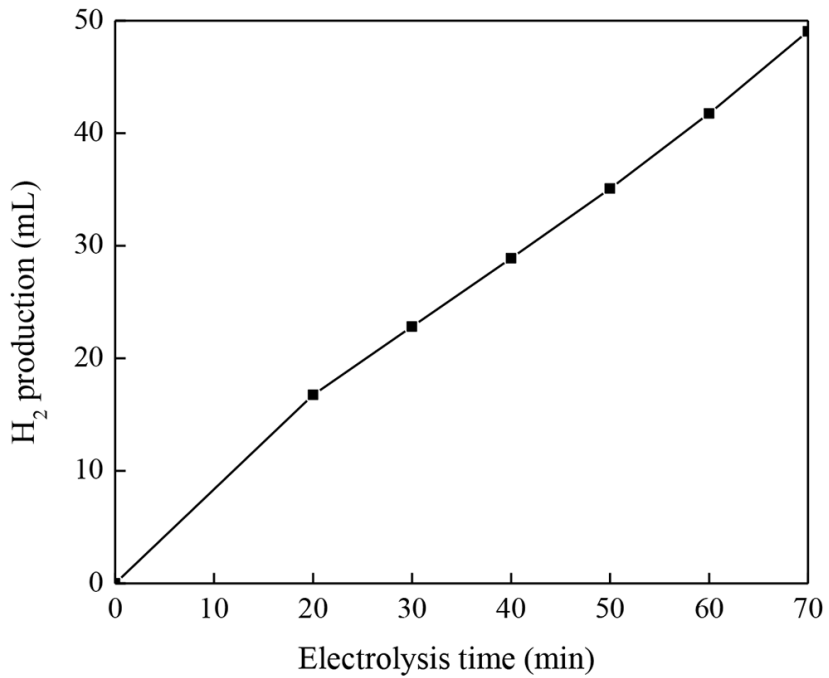

Fig. 2. $\mathrm{H}_{2}$ production of $\mathrm{Al}(+)-\mathrm{Al}(-)$ electrode combinations at different electrolysis times.

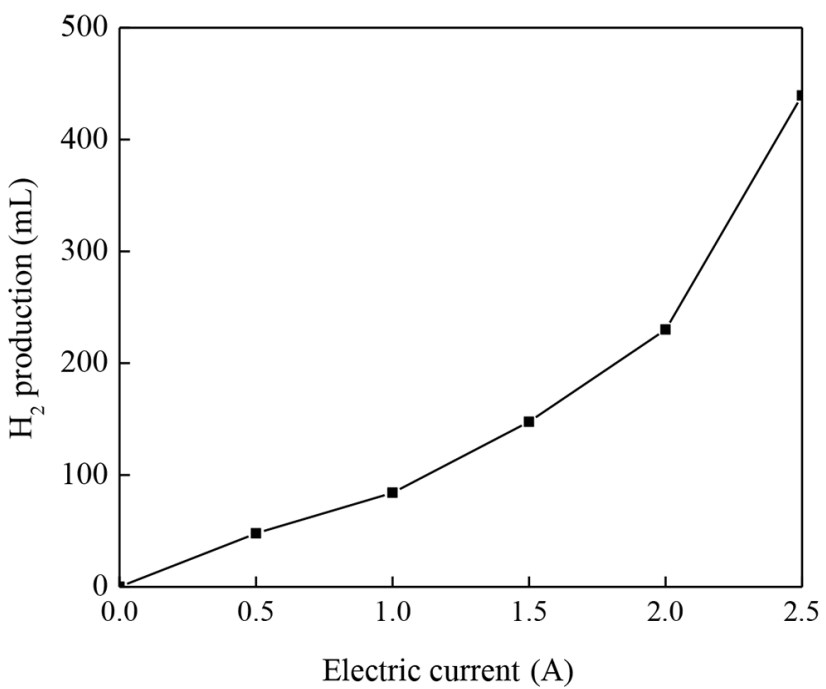

Fig. 3. $\mathrm{H}_{2}$ production of $\mathrm{Al}(+)-\mathrm{Al}(-)$ electrode combinations at different electric currents.

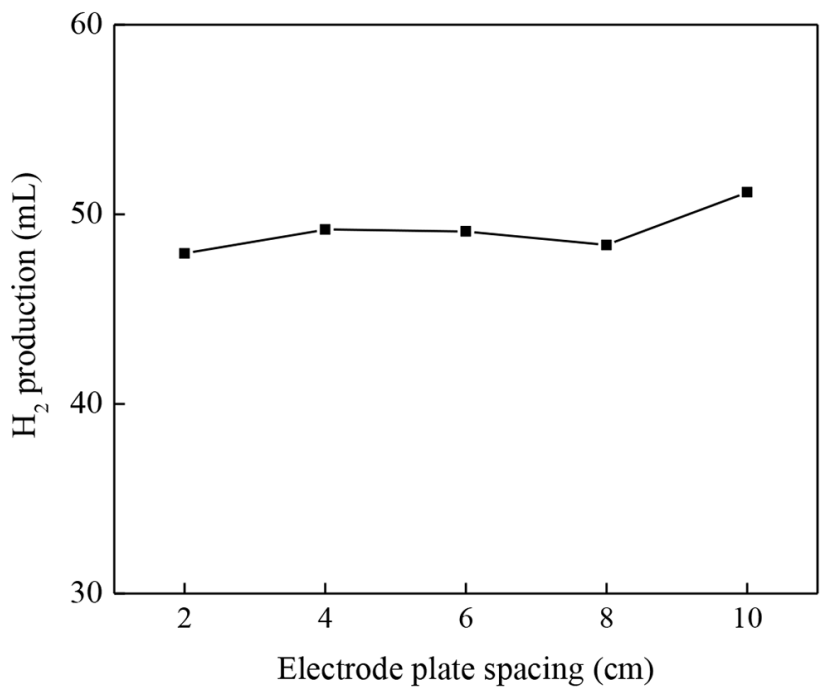

Fig. 4. $\mathrm{H}_{2}$ production of $\mathrm{Al}(+)-\mathrm{Al}(-)$ electrode combinations at different electrode plate spacings.

Anodic reaction:

$$
\mathrm{Al}-3 \mathrm{e} \rightarrow \mathrm{Al}^{3+}
$$

Cathodic reaction:

$$
2 \mathrm{H}^{+}+2 \mathrm{e} \rightarrow \mathrm{H}_{2} \uparrow
$$

Combination of the preceding analysis showed that a large $\mathrm{H}_{2}$ production was conducive to improving the turbidity removal and decolourisation rate of fracturing flow-back fluid by electrochemical treatment.

As shown in Fig. 4, no evident change was observed in the gas evolution of $\mathrm{H}_{2}$ between the $\mathrm{Al}(+)-\mathrm{Al}(-)$ electrode combinations with the increase in electrode plate spacing. This observation can be attributed to the Guangyuan oilfield fracturing flow-back 
fluid containing numerous ions, such as $\mathrm{Cl}^{-}$and $\mathrm{Na}^{+}$(initial concentration: $\mathrm{Na}^{+} 1,700 \mathrm{mg} / \mathrm{L} ; \mathrm{Cl}^{-} 7,000 \mathrm{mg} / \mathrm{L}$, the change of concentration was not obvious after electrochemical treatment), thereby the fluid has excellent conductivity $(19,000 \mu \mathrm{s} / \mathrm{cm})$. Thus, increasing the electrode plate spacing will not significantly reduce the current efficiency.

\subsection{Analysis of the Electrode Self-corrosion Potential, $\mathrm{O}_{2}$ Evolution and $\mathrm{Cl}_{2}$ Evolution Polarization Curve}

Tafel electrode polarization curves of the $\mathrm{Al}$ electrode and special $\mathrm{Ti} / \mathrm{RuO}_{2}-\mathrm{IrO}_{2}-\mathrm{PdO}$ are shown in Fig. 5(a) and (b), where the self-corrosion potentials of $\mathrm{Al}$ electrode and special $\mathrm{Ti} / \mathrm{RuO}_{2}-$ $\mathrm{IrO}_{2}$-PdO were -0.58 and $0.54 \mathrm{~V}$, respectively. The self-corrosion potential of the $\mathrm{Al}$ electrode, which was an active metal electrode, was extremely low. Thus, the $\mathrm{Al}$ electrode formed $\mathrm{Al}^{3+}$ due to the easy occurrence of electron loss in the electrolysis anode reaction. However, the special $\mathrm{Ti} / \mathrm{RuO}_{2}-\mathrm{IrO}_{2}-\mathrm{PdO}$ had a high self-corrosion potential and was an inert electrode. During
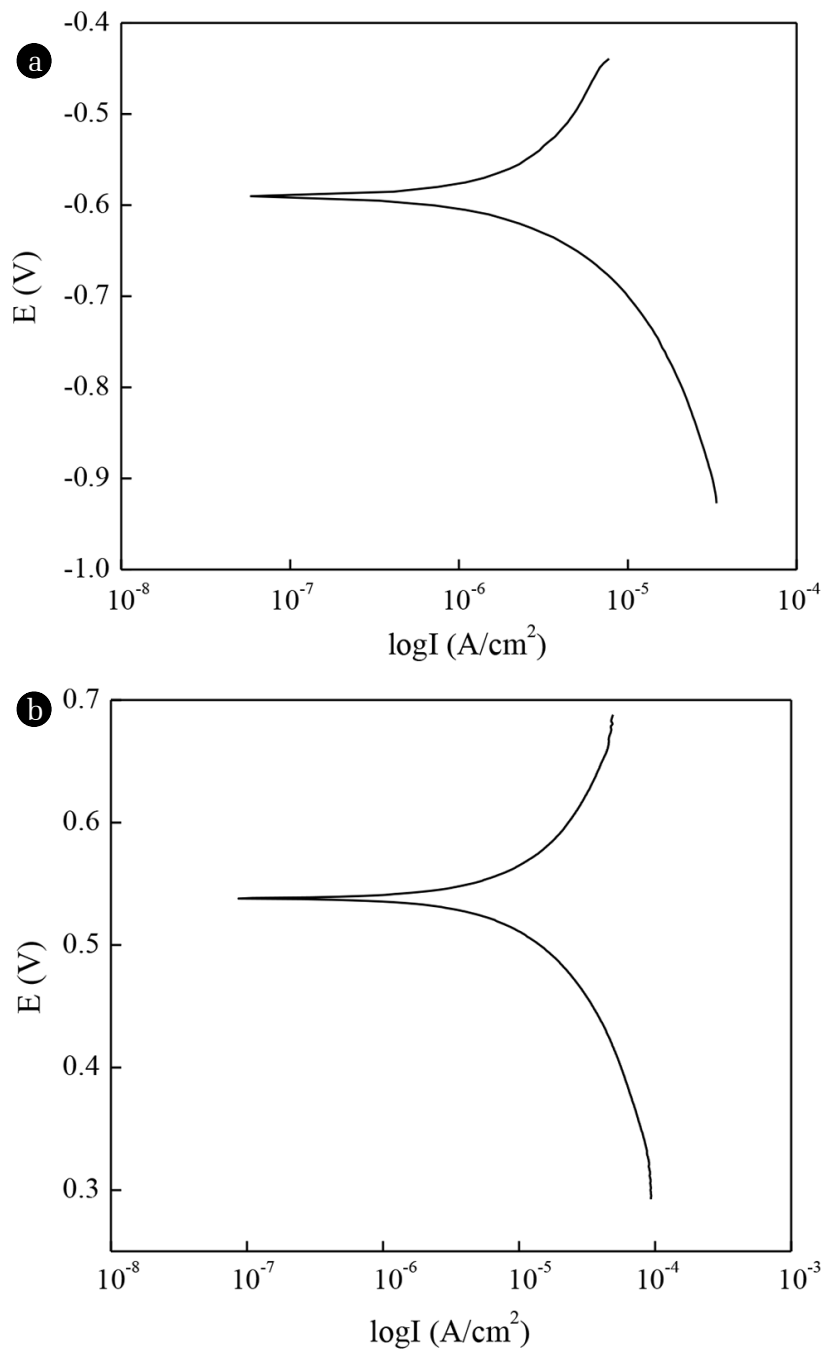

Fig. 5. The Tafel electrode polarization curves of $\mathrm{Al}$ electrode (a) and special $\mathrm{Ti} / \mathrm{RuO}_{2}-\mathrm{IrO}_{2}-\mathrm{PdO}(\mathrm{b})$. the electrolysis anode reaction, the electrode could not easily lose electrons. $\mathrm{OH}^{-}$or $\mathrm{Cl}^{-}$adsorbed on the electrode was relatively more likely to lose electrons, thereby producing $\mathrm{O}_{2}$ or $\mathrm{Cl}_{2}$.

In the case of an inert electrode, the self-corrosion potentials of different coated electrodes were also different, as shown in Table 4

Table 4 shows that the self-corrosion potential of the special $\mathrm{Ti} / \mathrm{RuO}_{2}-\mathrm{IrO}_{2}-\mathrm{PdO}$ in the fracturing fluid in Guangyuan oilfield was the highest, whereas the self-corrosion potential of zirconium electrode was the lowest. Generally, when the self-corrosion potential was high, the electrode was inert. Therefore, the inert electrodes in Table 4 were sorted according to their inertness during the electrolysis treatment of fracturing flow-back fluid in Guangyuan oilfield as follows: Special $\mathrm{Ti} / \mathrm{RuO}_{2}-\mathrm{IrO}_{2}-\mathrm{PdO}>$ $\mathrm{Ti} / \mathrm{RuO}_{2}-\mathrm{IrO}_{2}-\mathrm{PdO}>\mathrm{Ti} / \mathrm{RuO}_{2}-\mathrm{IrO}_{2}>$ special $\mathrm{Ti} / \mathrm{RuO}_{2}-\mathrm{IrO}_{2}>\mathrm{Ti}$ $>\mathrm{Zr}$.

Table 1 also shows that when the current and electrolysis time were the same and $\mathrm{Ti} / \mathrm{RuO}_{2}-\mathrm{IrO}_{2}$-PdO was used as anode, $\mathrm{H}_{2}$ production of each electrode combination was relatively low. However, the $\mathrm{H}_{2}$ production at each electrode combination significantly increased when the $\mathrm{Al}$ electrode was used as the anode. The inert electrode may generate $\mathrm{O}_{2}$ or $\mathrm{Cl}_{2}$ because the $\mathrm{Al}$ electrode mainly formed $\mathrm{Al}^{3+}$ during the anode reaction. The generated gas type $\left(\mathrm{O}_{2}, \mathrm{Cl}_{2}\right.$ or mixed gas of $\mathrm{O}_{2}$ and $\left.\mathrm{Cl}_{2}\right)$ of the inert electrode as an anode was clarified and its influence on $\mathrm{H}_{2}$ production of different cathodes was determined. The inert electrode special $\mathrm{Ti} / \mathrm{RuO}_{2}-\mathrm{IrO}_{2}-\mathrm{PdO}$ was used as an example to study the $\mathrm{O}_{2}$ evolution and the $\mathrm{Cl}_{2}$ evolution polarization curve as shown in Fig. 6(a) and (b), respectively.

Fig. 6(a) and (b) show that when special $\mathrm{Ti} / \mathrm{RuO}_{2}-\mathrm{IrO}_{2}-\mathrm{PdO}$ was used as the anode, evolutions of the $\mathrm{O}_{2}$ and $\mathrm{Cl}_{2}$ potential were 1.17 and $1.24 \mathrm{~V}$, respectively. Moreover, $\mathrm{O}_{2}$ evolution potential was lower than the $\mathrm{Cl}_{2}$ evolution potential, indicating that $\mathrm{O}_{2}$ was easier to generate than $\mathrm{Cl}_{2}$. Therefore, $\mathrm{O}_{2}$ was mainly generated from the anode. However, the difference between $\mathrm{O}_{2}$ evolution potential and $\mathrm{Cl}_{2}$ evolution potential was only 0.07 $\mathrm{V}$, indicating that the anode was also likely to generate $\mathrm{Cl}_{2}$. The use of an inert electrode as an anode in the processing of fracturing flow-back fluid in Guangyuan oilfield resulted in the production of $\mathrm{O}_{2}$ and $\mathrm{Cl}_{2} \cdot \mathrm{Cl}_{2}$ can be dissolved in aqueous solution and forms $\mathrm{HClO}$. After dissociation, it can form $\mathrm{ClO}^{-}$, which can obtain electrons from the cathode, thereby reducing the $\mathrm{H}_{2}$ production of the cathode. This finding also verified the results shown in Table 1 .

Table 4. Self-corrosion Potentials of Different Cathode Materials

\begin{tabular}{ccc}
\hline $\begin{array}{c}\text { Serial } \\
\text { number }\end{array}$ & Cathode material & $\begin{array}{c}\text { Self-corrosion } \\
\text { potentials/V }\end{array}$ \\
\hline 1 & $\mathrm{Ti}$ & 0.081 \\
2 & $\mathrm{Zr}$ & 0.047 \\
3 & Special $\mathrm{Ti} / \mathrm{RuO}_{2}-\mathrm{IrO}_{2}$ & 0.264 \\
4 & $\mathrm{Ti} / \mathrm{RuO}_{2}-\mathrm{IrO}_{2}$ & 0.275 \\
5 & $\mathrm{Special} \mathrm{Ti} / \mathrm{RuO}_{2}-\mathrm{IrO}_{2}-\mathrm{PdO}$ & 0.540 \\
6 & $\mathrm{Ti} / \mathrm{RuO}_{2}-\mathrm{IrO}_{2}-\mathrm{PdO}$ & 0.284 \\
\hline
\end{tabular}



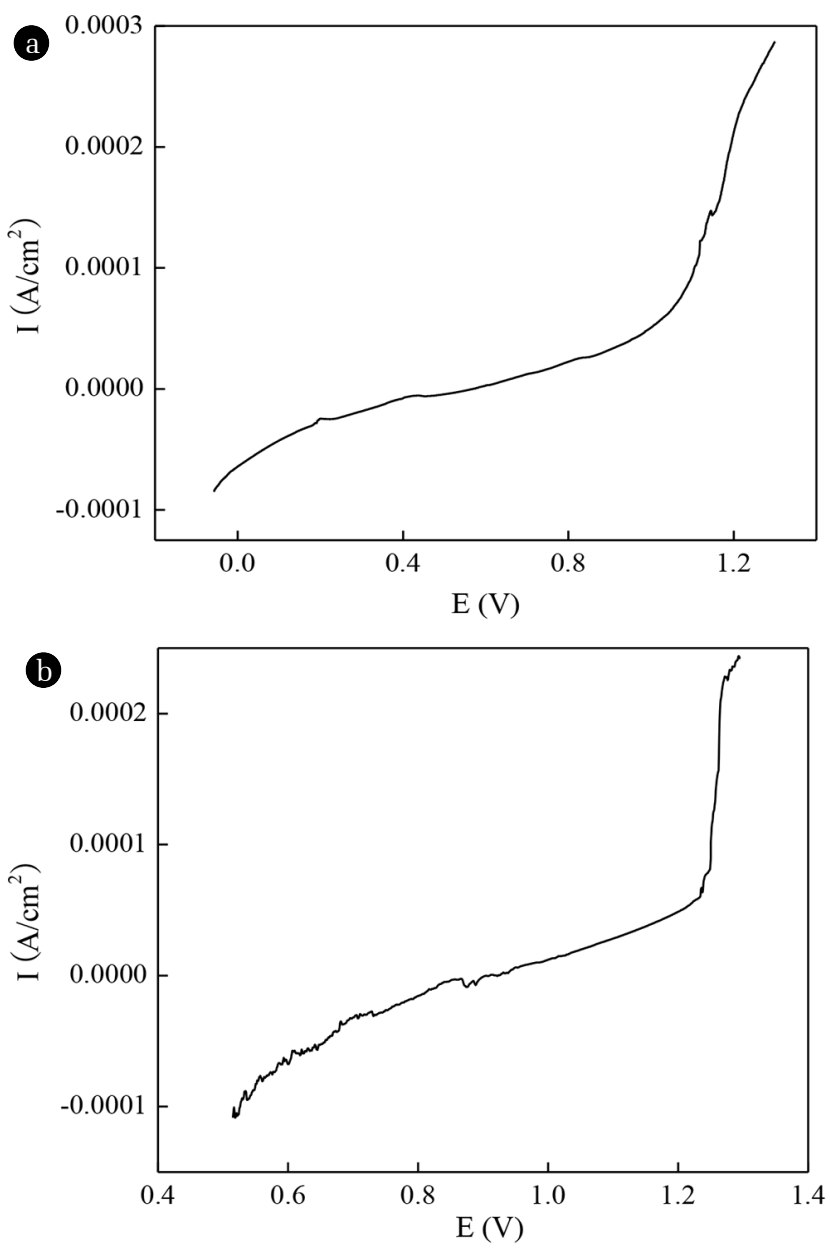

Fig. 6. The oxygen evolution polarization curve (a) and chloride evolution polarization curve (b) of a special $\mathrm{Ti} / \mathrm{RuO}_{2}-\mathrm{IrO}_{2}-\mathrm{PdO}$ as an anode.

Therefore, the reaction mechanism of inert electrode in Table 1 was speculated as follows:

Anodic reaction:

$$
\begin{gathered}
\mathrm{H}_{2} \mathrm{O}-2 \mathrm{e} \rightarrow \mathrm{O}_{2} \uparrow+2 \mathrm{H}^{+} \\
2 \mathrm{Cl}^{-}-2 \mathrm{e} \rightarrow \mathrm{Cl}_{2} \uparrow \\
\mathrm{Cl}_{2}+\mathrm{H}_{2} \mathrm{O} \rightarrow \mathrm{ClO}^{-}+2 \mathrm{H}^{+}+\mathrm{Cl}^{-}
\end{gathered}
$$

Cathodic reaction:

$$
\mathrm{ClO}^{-}+\mathrm{H}_{2} \mathrm{O}+2 \mathrm{e} \rightarrow 2 \mathrm{Cl}^{-}+2 \mathrm{OH}
$$

\section{Conclusions}

i ) The combination of electrode material and electrode significantly affected $\mathrm{H}_{2}$ evolution. When the anode and cathode materials were both inert electrodes, $\mathrm{H}_{2}$ production was low, and the anode material was a soluble $\mathrm{Al}$ electrode; therefore, $\mathrm{H}_{2}$ production was high.

ii) A large amount of $\mathrm{H}_{2}$ led to the high turbidity removal and decolourisation rate of the electrode combination was used for the treatment of fracturing flow-back fluid in the Guangyuan oilfield.

iii) Under the same current and electrolysis time, the energy consumption of cathodic material using soluble $\mathrm{Al}$ electrode was lower than that of the inert electrode.

iv) The turbidity removal and decolourisation rate of fracturing flow-back fluid were highest using $\mathrm{Al}(+)-\mathrm{Al}(-)$ electrode combination. Prolonged electrolysis time and increasing the current can significantly enhance $\mathrm{H}_{2}$ production, especially, electrolysis current played an important role in $\mathrm{H}_{2}$ production.

v) When inert electrode was used as an anode for the treatment of fracturing flow-back fluid in Guangyuan oilfield, the main anodic gases were $\mathrm{O}_{2}$ and $\mathrm{Cl}_{2}, \mathrm{Cl}_{2}$ can be dissolved in aqueous solution to form $\mathrm{ClO}^{-}$after dissociation. The dissolution reduces the amount of $\mathrm{H}_{2}$ produced by the cathode.

\section{Acknowledgments}

The authors of this work wish to gratefully acknowledge the financial support from The Key Technologies R\&D Program of China (No.2016ZX05040003-008-001).

\section{References}

1. Zhang F, Shen Y, Wang L, Ma G, Su Y, Ren T. Synthesis and properties of polyacrylamide drag reducer for fracturing fluid. Chem. Ind. Eng. Prog. 2016;33:3640-3644 (in Chinese).

2. Ye D, Wang S, Cai Y, Ren Y, Luo C. Application of continuously mixing fracturing fluid and such flow process. Nat. Gas Ind. 2013;33:47-51 (in Chinese).

3. Yang Z, Wei Y, Lu L, Zhang S, Wang Z. Research and application of recycling treatment technology for shale gas fracturing flowback fluid: A case study. Nat. Gas Ind. 2015;35:131-137 (in Chinese).

4. Valero E, Álvarez X, Cancela Á, Sánchez Á. Harvesting green algae from eutrophic reservoir by electroflocculation and post-use for biodiesel production. Bioresour. Technol. 2015; 187:255-262.

5. Moheimani NR, Tetraselmis S. Culture for $\mathrm{CO}_{2}$ bioremediation of untreated flue gas from a coal-fired power station. J. Appl. Phycol. 2016;28:2139-2146.

6. Vivek JP, Burgess IJ. Insight into chloride induced aggregation of DMAP-monolayer protected gold nanoparticles using the thermodynamics of ideally polarized electrodes. J. Phys. Chem. C 2016;112:2872-2880.

7. Gómez-López VM, Gil MI, Pupunat L, Allende A. Cross-contamination of Escherichia coli O157:H7 is inhibited by electrolyzed water combined with salt under dynamic conditions of increasing organic matter. Food Microbiol. 2015;46:471-478.

8. Tanneru CT, Rimer JD, Chellam S. Sweep flocculation and adsorption of viruses on aluminum flocs during electro- 
chemical treatment prior to surface water microfiltration. Environ. Sci. Technol. 2013;47:4612-4618.

9. Zhao W, Zhu H, Zong Z, Xia J, Wei X. Electrochemical reduction of pyrite in aqueous NaCl solution. Fuel 2005;84:235-238.

10. Sánchez J, Butter B, Rivas BL, Basáez L, Santander P. Electrochemical oxidation and removal of arsenic using water-soluble polymers. J. Appl. Electrochem. 2015;45:151-159.

11. Sopaj F, Rodrigo MA, Oturan N, Podvorica FI, Pinson J, Oturan MA. Influence of the anode materials on the electrochemical oxidation efficiency. Application to oxidative degradation of the pharmaceutical amoxicillin. Chem. Eng. J. 2015;262: 286-294.

12. Alvarezpugliese CE, Morenowiedman P, Machucamartínez F, Marriagacabrales N. Distillery wastewater treated by electrochemical oxidation with boron-doped diamond electrodes. J. Adv. Oxid. Technol. 2016;14:213-219.

13. Geng Z, Wang X, Guo X, Zhang Z, Chen Y, Wang Y. Electrodeposition of chitosan based on coordination with metal ions in situ-generated by electrochemical oxidation. J. Mater. Chem. B 2016;4:3331-3338.

14. Chen WF, Muckerman JT, Fujita E. Recent developments in transition metal carbides and nitrides as hydrogen evolution electrocatalysts. Chem. Commun. 2013;49:8896-8909.
15. Ci SQ, Mao S, Hou Y, et al. Rational design of mesoporous $\mathrm{NiFe}$-alloy-based hybrids for oxygen conversion electrocatalysis. J. Mater. Chem. A 2015;3:7986-7993.

16. Zeng F, Luo X. Determination of the colority of water samples by spectrophotometry. Ind. Water Treat. 2006;26:69-77 (in Chinese).

17. Jang SH, Lee JH. Fabrication of nickel cobalt oxide electrode by in situ electrochemical method for the oxygen evolution anodes in water electrolysis system. J. Nanosci. Nanotechnol. 2016;16:11326-11329.

18. Swesi AT, Masud J, Nath M. Nickel selenide as a high-efficiency catalyst for oxygen evolution reaction. Energ. Environ. Sci. 2016;9:1771-1782.

19. Schaefer H, Sadaf S, Walder L, et al. Stainless steel made to rust: A robust water-splitting catalyst with benchmark characteristics. Energ. Environ. Sci. 2015;8:2685-2697.

20. Mouedhen G, Feki M, Wery MP, Ayedi HF. Behavior of aluminum electrodes in electrocoagulation process. J. Hazard. Mater. 2008;150:124-135.

21. Pournaghi-Azar MH, Razmi-Nerbin H. Electroless preparation and electrochemistry of nickel-pentacyanonitrosylferrate film modified aluminum electrode. Electroanalysis 2015;12:209-215. 